\title{
インバータモータの電磁振動解析*
}

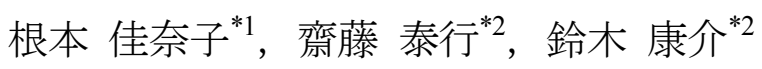

\section{Frequency Response Analysis of Electromagnetically Induced Vibration of Inverter Motors}

\author{
Kanako NEMOTO ${ }^{* 1}$, Yasuyuki SAITO and Kosuke SUZUKI \\ ${ }^{* 1}$ Hitachi Research Laboratory, Hitachi Ltd., \\ 832-2, Horiguchi, Hitachinaka, Ibaraki, 312-0034 Japan
}

\begin{abstract}
Vibration and noise need to be calculated with a high degree of accuracy to estimate the radiated noise and vibration induced by the electromagnetic force from a motor. In the case of inverter motors, changes in rotation speed and load lead to changes in exciting frequencies and amplitudes of electromagnetic force harmonics. We developed a way to analyze frequency responses of electromagnetically induced vibration using the electromagnetic force in a representative revolution speed in the above conditions. We measured and calculated a sample motor's vibration induced by electromagnetic force of time order harmonics, which has a dominant effect on the overall vibration, and we compared levels of vibration velocity. We calculated both rotation speeds and vibration velocity levels, which had three observable peaks with a high degree of accuracy.
\end{abstract}

Key Words : Electromagnetic Induced Vibration, Computational Mechanics, Structural Analysis, Frequency Response, Inverter Motor

\section{1. 緒言}

近年, $\mathrm{CO}_{2}$ 排出量削減を目的として, 動力源の内燃機関からモーターの置き換えが進められている. それと同 時に, 快適な生活環境実現への要望も大きくなっている. 一方, モータの高出力化や小型·軽量化に伴い, 振動・ 騷音の問題が発生しや寸くなっている.

上記要請に応えるため, 設計段階で解析によりモータの振動や騒音を予測し, 短期間で低振動・低騒音な製品 を開発できる技術が望まれ, 電磁場, 構造, 音場解析 3 つを活用した振動・騒音予測, 低減が試みられている(1)(2) 筆者らは 2 次元電磁場解析で求められた電磁力高調波をもとに, 径方向の電磁力高調波によって励起される振 動・騒音を 3 次元で解析し, 電磁力高調波と構造系固有モードの共振の度合いを判定する指標について報告した (3). さらには, モータの振動・騒音を計算するための加振力として径方向の成分だけでなく, 接線方向の成分も 考慮した場合の，振動・騒音スペクトル計算を行い，一定回転数において騒音に影響する振動ピークを精度よく 計算できる結果を得た ${ }^{(4)}$ 。

インバータモータは回転数一定のモータとは異なり, 回転数により振動・騒音のスペクトル, レベルが変化す る. 回転範囲が広いインバータモータでは, 特定の回転数において特定の時間次数の相対的に大きな振動・騒音 ピークが現れることがある．インバータモータの振動・騒音を低減するには，まずこの相対的に大きな振動・騒 音ピークを予測する必要がある.

本報告では，上記手法をインバータモータに適用し，代表的な回転数に対する電磁加振力を入力として振動に 支配的な時間次数の振動解析を行い, 計算值と測定值を比較することにより, 測定值で相対的に大きな複数の振 動ピークを計算値と測定值の差土4dB 以下で精度良く求められることを確認した.

\footnotetext{
* 原稿受付 2011 年 9 月 17 日

*1 正員, (株) 日立製作所日立研究所（广312-0034 茨城県ひたちなか市堀口 832-2）

*2 (株) 日立オートモティブシステムズ（テ312-8503 茨城県ひたちなか市大字高場 2520)

E-mail:kanako.nemoto.ns@hitachi.com
} 


\section{2. 電磁振動の解析・測定}

\section{$2 \cdot 1$ 解析手順および解析対象のモ一タ}

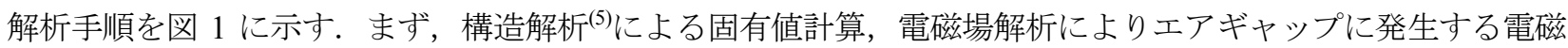
力の計算とその高調波解析を実施する. 次に，電磁力高調波を構造系への加振力に変換して振動応答解析 ${ }^{(5)}$ 実 施し，音場解析の境界条件となる構造表面の振動速度を計算する．最後に，振動応答解析結果を入力として音場 解析 ${ }^{(6)}$ を実施し，音圧を計算する。

図 2 に示寸実験装置を用いて, 試験用モータの振動速度について, 実験により求めた值と, 上記手順により計 算で求めた值とを比較する.

\begin{tabular}{|c|c|c|}
\hline Structure analysis & Frequency response & Frequency response \\
\hline $\begin{array}{c}\text { Electromagnetic analysis } \\
\text { Harmonics analysis }\end{array}$ & $\begin{array}{c}\text { analysis } \\
\text { (Vibration velocity) }\end{array}$ & $\begin{array}{c}\text { analysis } \\
\text { (Sound pressure level) }\end{array}$ \\
\hline
\end{tabular}

Fig. 1 Analysis flow

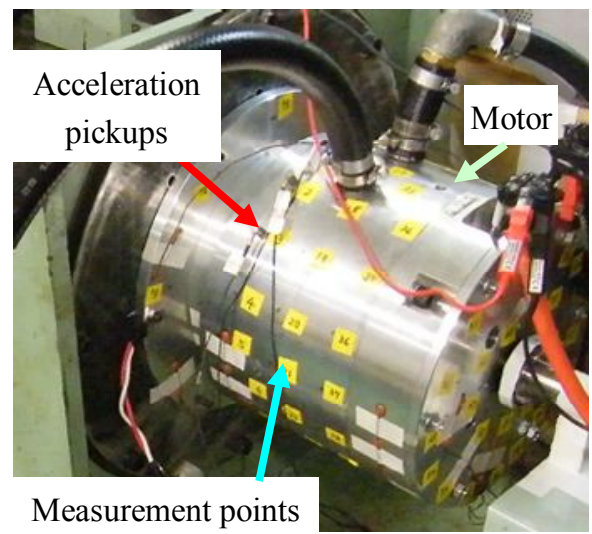

(a) Measurement setup

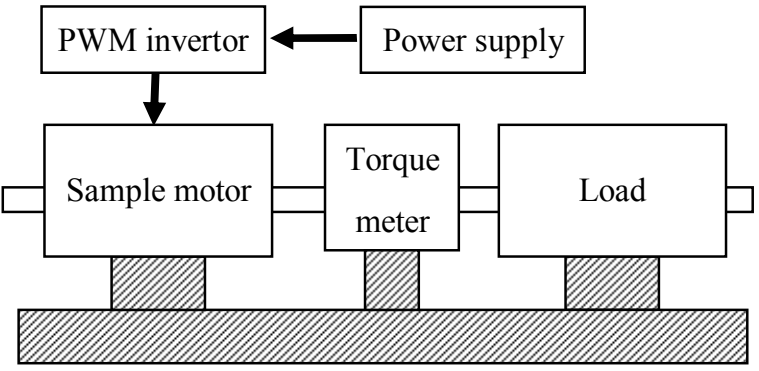

(b) Motor driving system

Fig. 2 Experimental setup

\section{$2 \cdot 2$ 電磁力の高調波解析}

モータではステータ，ロータの間の空間，エアギャップと呼ばれる部分に磁束が集中し，電磁力が発生する. ステータコア，ロータコア，巻線，磁石の形状が軸方向で同じ場合，ステータコアとロータコアが存在する軸方 向の任意断面のエアギャップで発生する電磁力は同じ空間分布とみなすことができ，軸方向に垂直な断面でステ 一タコア，ロータコア，巻線，磁石，空間を 2 次元有限要素でモデル化し，電磁場解析を行うことができる.

2 次元電磁場解析により求めたエアギャップに発生する電磁力には高調波成分が含まれ，時間と空間の関数と なっている. 電磁力を径方向と接線方向の成分に分解し，それぞれを時間と空間でフーリエ級数に展開寸ると次 式が得られる(7) . 


$$
\sigma=\sum_{n} \sum_{l} a_{n l} \sin \left(n \theta-l \omega t+\alpha_{n l}\right)
$$

ここで, $\sigma$ : 径方向または接線方向の単位面積当たりの電磁力 $[\mathrm{Pa}], n$ : 空間次数, $l:$ 回転次数 (=時間次数 $\times$ 極対数), $a_{n l}$ : 空間 $n$ 次, 回転 $l$ 次高調波成分の振幅 $[\mathrm{Pa}], \theta$ : 機械角 $[\mathrm{rad}], \omega(=2 \pi f)$ : 基本角周波数 $[\mathrm{rad} / \mathrm{s}]$, $f:$ 基本周波数 $[\mathrm{Hz}], t:$ 時間 $[\mathrm{s}], \alpha_{n l}$ : 空間 $n$ 次, 回転 $l$ 次高調波成分の位相角 $[\mathrm{rad}]$ である.

インバータモータの負荷は回転数により変化し, 負荷の変動によって電磁力高調波の振幅, 位相が変化する. そこで, 複数の代表的な回転数について電磁力高調波を計算し, その前後の回転数, (代表的な回転数一回転数刻 み/2）から（代表的な回転数十回転数刻み/2）の範囲の振動応答解析には，代表的な回転数の電磁力高調波を用 いる.

\section{$2 \cdot 3$ 構造のモデル化}

図 3 (a) に示寸モータの構造振動応答解析モデルは, ハウジングなど大部分の部品については 3 次元 CAD の データからソリッド要素を用いて作成した，ただし，ステータコアとコイルは，節点数を抑えるためステータコ アの実形状を 3 次元 CAD のデータからソリッド要素を用いて忠実にモデル化し，コイルを付加質量とした図 3

（b）のモデルを用いた．ステータコアの密度は $1.01 \times 10^{4} \mathrm{~kg} / \mathrm{m}^{3}$ である. ステータコアの等価ヤング率は, 構造解 析により求められる固有振動数と, コイルを巻線した状態でステータコアを打撃試験することにより得られる固 有振動数とが一致するように調整して得られた $196 \mathrm{GPa}$ である.

また，モータ支持部について振動の解析結果と測定結果とが合うように，モータと結合する周辺部分もソリッ ド要素でモデル化して結合条件の合わせこみを行い, 高精度化を図った. 全部でモデルの節点数は 276591 , 要素 数は 161686 である.

次に, 構造系への加振力について説明する. 構造系への加振力は, 径方向, 接線方向の単位面積当たりの電磁 力 $\sigma$ または電磁力高調波に, 加振面の面積をかけて力に变換し, 加振面を構成する各節点に振り分けることによ り得られる (3). 得られた構造系への加振力の径方向成分を $F_{r}$, 接線方向成分を $F_{t}$ と表記する. 構造振動応答解析 は線形解析なので, 解析結果を後で重ね合わせることが可能である. そこで, 構造系への加振力は全てのティー ス先端に図 3 (c) に示した径方向成分 $F_{r}$ と接線方向成分 $F_{t}$ を独立に入力する.

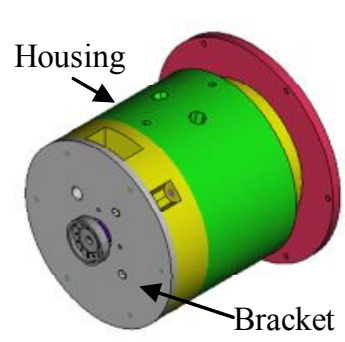

(a) Motor model

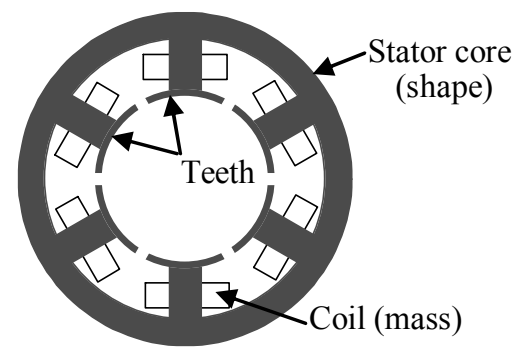

(b) Stator core (cross-section shape)

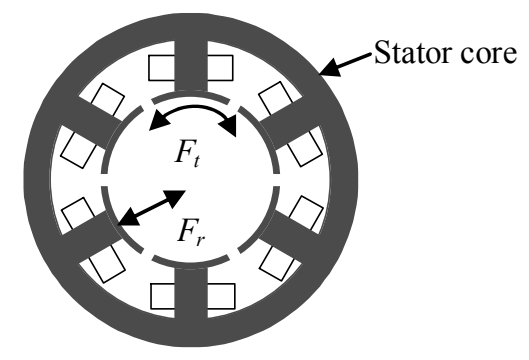

(c) Electromagnetic force (cross-section shape)

Fig. 3 Motor calculation model

\section{$2 \cdot 4$ 測定結果}

図 4 にトルクリプル高調波の次数である時間 6 次, 12 次, 18 次, 24 次の平均加速度を示す. 縦軸は $5000 \mathrm{r} / \mathrm{min}$ のオーバーオールを $0 \mathrm{~dB}$ として表記している. 平均加速度は図 2 (a) に示したハウジング外周部でステータコア が存在する軸方向範囲の 3 断面, 円周上 16 箇所, ブラケット部 24 箇所, 合計 72 箇所に振動ピックアップを取り 付け, 得られた加速度の測定值を平均化した結果である. これより, 振動のオーバーオールに対する寄与が大き い時間次数は，時間 12 次， 24 次であることが分かった．以下，時間 12 次， 24 次を解析対象とする.

なお, 図 4 の縦軸が図 5, 図 6 と違って加速度表示になっているのは, 加速度測定值から速度のオーバーオー ルを求められないため, 加速度から振動のオーバーオールに対する時間次数の寄与を判断したためである. 


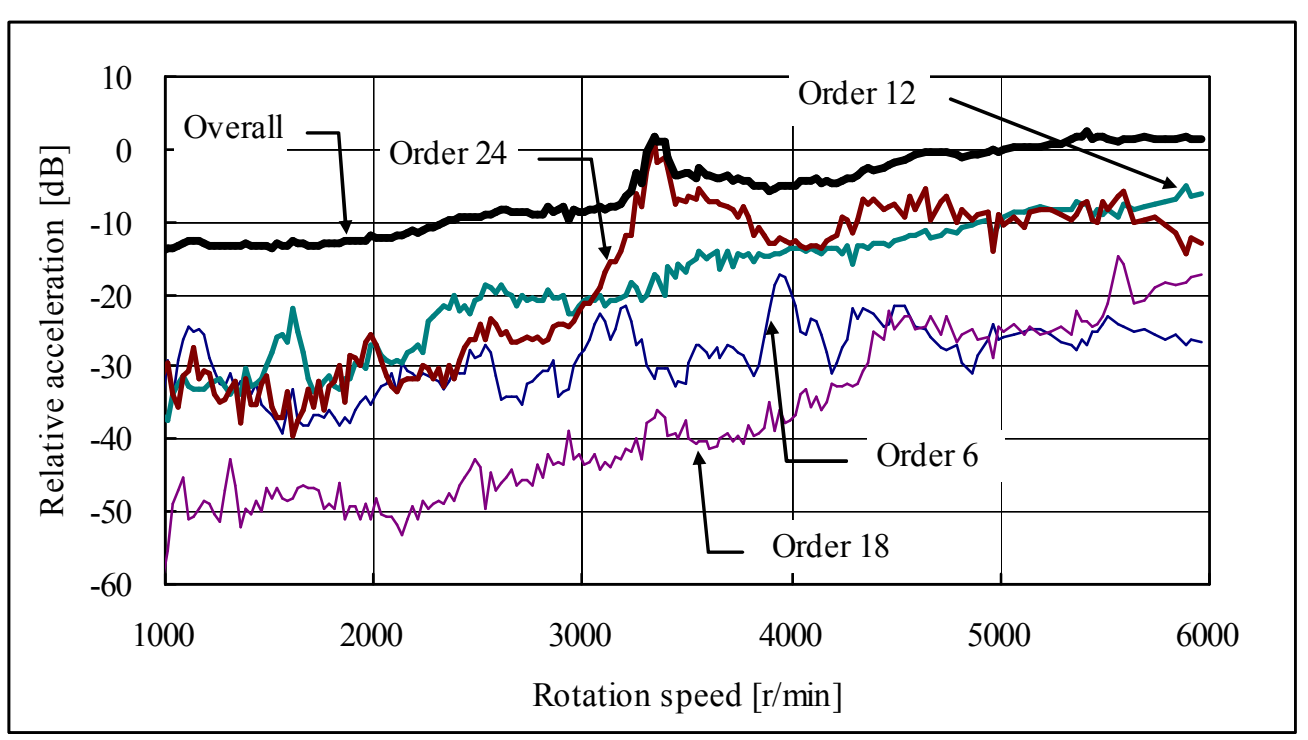

Fig. 4 Averaged measurement acceleration

\section{$2 \cdot 5$ 解析結果}

図 5 に時間 12 次, 図 6 に時間 24 次の電磁力高調波を入力した時の振動速度レベル（Vibration Velocity Level (VVL)）の計算值を示す．また，測定值も併せて示す．縦軸は計算值，測定值とも時間 12 次の $5000 \mathrm{r} / \mathrm{min}$ の測 定值を $0 \mathrm{~dB}$ として表記している. 図 5, 図 6 中の測定值は図 2 (a) に示した 72 箇所の值を平均化したものであ る. 図 5 の測定值，計算值とも $1500 \mathrm{r} / \mathrm{min}$ 近傍， $6700 \mathrm{r} / \mathrm{min}$ 近傍の 2 箇所，相対的に大きなピークが存在する. 解 析精度は, 1500r/min 近傍でレベル差 1.4dB, 6700r/min 近傍ではレベル差-1.5dB となっており精度良く求まってい る. 図 6 には 3350r/min 近傍に測定值と計算值に共通して相対的に大きなピークが存在し, ピーク差は-3.7dB と なっている，時間 24 次における計算值は，時間 12 次と同様に，測定值におけるピーク回転数およびレベルをほ ぼ捉えられていることが分かる.

以上より，インバータモータの時間 12 次, 24 次の測定值で相対的に大きな 3 箇所の振動ピークについて, 計 算值と測定值がよく一致する結果が得られることがわかった.

なお，図 5 の計算值 $2100 \mathrm{r} / \mathrm{min} ， 4800 \mathrm{r} / \mathrm{min} ， 5600 \mathrm{r} / \mathrm{min}$ ，図 6 の計算值 $1000 \mathrm{r} / \mathrm{min}$ 近傍には測定値では見られない ピークが存在する．これは負荷側をモデル化せずモータ単体で評価したことが原因と考えられ，今後負荷側をモ デル化した検討が必要である.

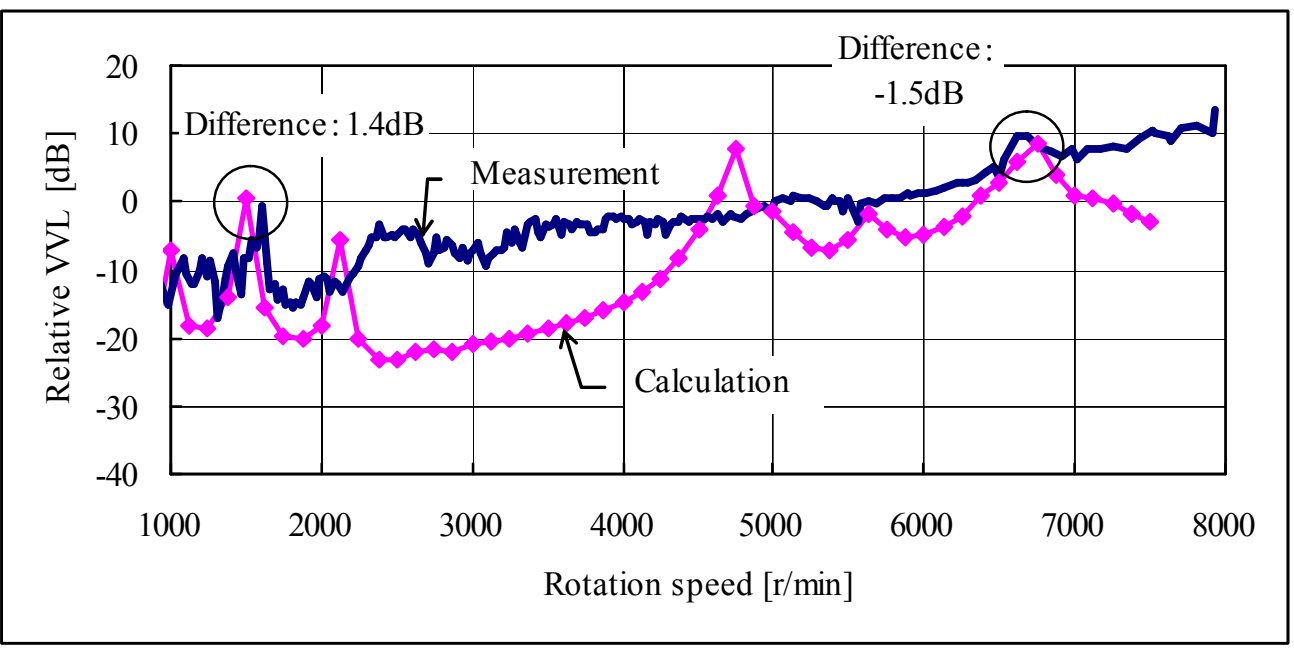

Fig. 5 Comparison between calculation and measurement of vibration velocity level (VVL) at order 12 


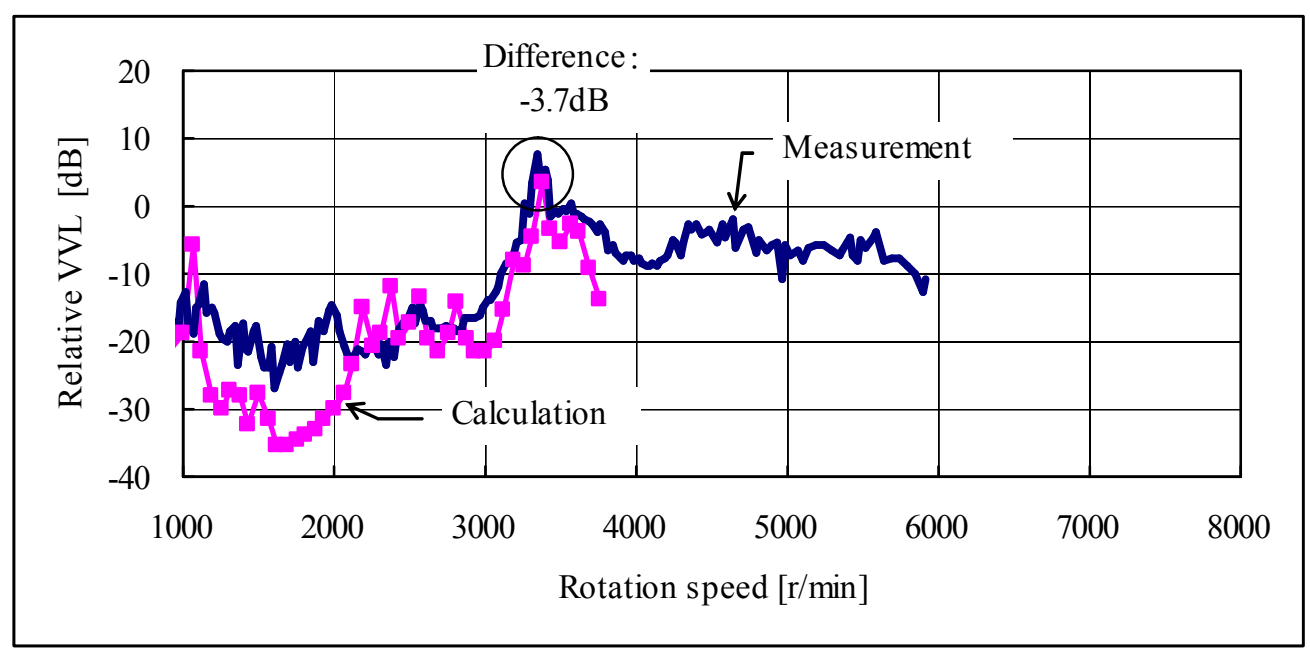

Fig. 6 Comparison between calculation and measurement of vibration velocity level (VVL) at order 24

\section{3. 結 語}

インバータモータを対象に電磁加振力による振動の計算值と測定值との比較を行い, 以下の結論を得た.

（1）代表的な回転数の径方向と接線方向の電磁力高調波を用いて, 振動ピークを予測できる解析手法を開発し た.

（2）上記手法とモータ支持部モデルの高精度化により，時間 12 次，時間 24 次の測定值で相対的に大きな 3 箇所の振動速度レベルピークの計算值が，測定值と差士 $4 \mathrm{~dB}$ 以下で精度良く求められることを確認した。

\section{文献}

（1）石橋文徳，野田伸一，森貞明，“小形誘導電動機の電磁振動について “, 電気学会論文誌 D, Vol. 112, No. 3 (1992), pp. 307-313.

（2）Sun X, 刑部年彦，桑野雅幸，足立勇，村瀬純一，“整流を考慮した DC モー夕の磁気加振力解析 “, 電気学会回転 機研究会資料，Vol.RM-02，No.133-144 (2002), pp. 19-23.

（3）塩幡宏規，根本佳奈子，名川泰正，坂本茂，小林孝司，伊藤元哉，小原木春雄，“電磁力励起による電動機の振動 放射音解析法”，電気学会論文誌 D, Vol. 118，No. 11 (1998), pp. 1301-1307.

(4) 根本佳奈子, 高野靖, 高畑良一, 日野徳昭, 島和男, “モ一夕電磁振動音の解析手法の検討 “, 日本機械学会 環境工学総合シンポジウム講演論文集, Vol.16th (2006), pp. 133-136.

(5) エムエスシーソフトウェア, “設計者のための CAE 活用ガイド 製品紹介編 MSC.Software Virtual Product Development”, 機械設計, Vol. 48, No. 5 (2004), pp. 78-83.

(6) Autrique, J.C. and Magoules, F. , "Studies of an infinite element method for acoustical radiation", Applied Mathematical Modelling, Vol. 30, No. 7 (2006), pp. 641-655.

(7) Kobayashi, T., Tajima, F., Ito M., and Shibukawa, S., "Effects of Slot Combination on Acoustic Noise from Induction Motors", IEEE Transactions on Magnetics, Vol. 33, No .2 (1997), pp. 2101-2104. 